\title{
DAMPAK KOMERSIALISASI PENDIDIKAN TERHADAP TATA KELOLA PENDIDIKAN TINGGI DI INDONESIA ${ }^{1}$
}

\author{
Achmad Zulfikar \\ Program Studi Ilmu Hubungan Internasional \\ Universitas Muhammadiyah Yogyakarta \\ Email: apa@kabarfikar.com
}

\begin{abstract}
This paper aims to examine the impact of commercialization on higher education governance in Indonesia and examine strategies that can be used by higher education to face the impact of commercialization. This study uses literature study. The results of the study indicate that there are three impacts caused by the commercialization of education on higher education governance i.e. the impact on academic standards, the spirit of collegiality and trust among the academic community and the image of universities in the public. Strategies that can be undertaken for public higher education, among others, maintain the quality of education and keep the pattern of access to students stay on the track, and seek forms of capital collection to finance education through the banking channel. While for private higher education, a strategy that can be done is to coordinate with Kopertis (Coordinator of Private Higher Education), improve the quality of education through the development of students' skills and efficiency of expenditures that are not a priority to reduce education costs.
\end{abstract}

Keywords: Comercialization of Education, Governance, Higher Education

\begin{abstract}
Abstrak
Tulisan ini bertujuan untuk mengkaji dampak komersialisasi terhadap tata kelola pendidikan tinggi di Indonesia dan mengkaji strategi yang dapat digunakan oleh pendidikan tinggi dalam menghadapi dampak komersialisasi. Kajian ini menggunakan studi pustaka. Hasil kajian menunjukkan bahwa terdapat tiga dampak yang ditimbulkan oleh komersialisasi pendidikan terhadap tata kelola pendidikan tinggi yakni dampak terhadap standar akademik, semangat kolegialitas dan kepercayaan di antara civitas akademika dan citra perguruan tinggi di mata publik. Strategi yang dapat dilakukan untuk pendidikan tinggi negeri antara lain mempertahankan mutu pendidikan dan menjaga pola akses masuk anak didik tetap pada jalur semestinya, dan mengusahakan bentuk-bentuk pengumpulan modal untuk membiayai pendidikan melalui jalur perbankan. Sedangkan untuk pendidikan tinggi swasta, strategi yang dapat dilakukan yakni melakukan koordinasi dengan Kopertis, meningkatkan mutu pendidikan melalui pengembangan kemampuan siswa dan melakukan efisiensi terhadap pengeluaran yang tidak prioritas untuk menekan terjadinya lonjakan biaya pendidikan.
\end{abstract}

Kata Kunci: Komersialisasi Pendidikan, Tata Kelola, Pendidikan Tinggi

\footnotetext{
${ }^{1}$ Makalah telah dikompetisikan dalam Call for Paper Eduforia Tahun 2012 yang diselenggarakan oleh Badan Eksekutif Mahasiswa Universitas Muhammadiyah Yogyakarta.
} 


\section{BAB I. PENDAHULUAN}

\section{A. Latar Belakang Masalah}

Pendidikan merupakan kewajiban negara kepada rakyatnya yang telah diamanatkan oleh Undang-Undang Dasar 1945. Lebih tepatnya amanat tersebut telah tercantum pada alinea ke-empat UUD 1945 yang berbunyi, "pemerintah Negara Indonesia berkewajiban mencerdaskan kehidupan bangsa". Lebih lanjut pada pasal 31 UUD 45 ayat 1 juga dicantumkan: "Tiap-tiap warga Negara berhak untuk mendapatkan pengajaran".

Pendidikan yang dimaksud dalam UUD 1945 bukan hanya mencakup pada wajib belajar 9 tahun saja. Namun yang perlu kita sadari bahwa, pendidikan tersebut mencakup pendidikan yang bersifat sepanjang hayat. Selama ini, pendidikan yang kerap disoroti adalah pendidikan di tingkatan Sekolah Dasar, Sekolah Menengah Pertama, maupun Sekolah Menegah Atas. Yang seringkali dilupakan adalah pendidikan tinggi.

Pendidikan tinggi ini seringkali diidentikkan peruntukannya hanya untuk kaum yang mampu saja (secara finansial). Sedangkan kita ketahui bahwa pendidikan merupakan hak seluruh warga negara tanpa terkecuali. Di samping itu, tingginya tingkat pendidikan juga terkait dengan indikator kemajuan suatu bangsa.

Hal ini juga dapat dilihat pada kecendrungan dunia pendidikan sebagai komoditas yang diperjual belikan. Fakta yang dapat kita amati di lapangan memperlihatkan lembagalembaga pendidikan tinggi dengan status yang kurang jelas tumbuh subur terutama di kota besar. Dengan berbagai cara mereka mengiklankan dan menawarkan program pendidikan untuk mendapatkan gelar seperti MBA (Magister of Bussiness Administration), atau MM (Magister Management) tanpa melalui proses pembelajaran. Lembaga seperti ini telah merusak nama baik institusi pendidikan, karena lebih mementingkan keuntungan daripada mutu.

Fakta di atas dapat kita kategorisasikan kedalam bentuk-bentuk komersialisasi pendidikan, dan juga merupakan suatu masalah yang lambat laun bakal memicu tumbuhnya culture capitalism maupun ideologi neo-liberalisme di lembaga pendidikan Tinggi di Indonesia dengan modus klasik "komersialisasi pendidikan". Kondisi ini tentunya akan memberikan dampak secara langsung maupun tidak terhadap pendidikan tinggi di Indonesia, khususnya dalam tata kelola pendidikan tinggi, maupun strategi yang kiranya dapat diaplikasikan untuk menghadapi dampak dari komersialisasi pendidikan tersebut.

\section{B. Rumusan Masalah}

1. Apakah dampak komersialisasi terhadap tata kelola Pendidikan Tinggi di Indonesia?

2. Bagaimanakah strategi Pendidikan Tinggi dalam menghadapi dampak Komersialisasi? 


\section{BAB II . PEMBAHASAN}

\section{A. Tinjauan terhadap Makna Komersialisasi Pendidikan}

Komersialisasi Pendidikan dapat bermakna memperdagangkan pendidikan, hal ini didasarkan pada arti kata komersial atau commercialize yang berarti memperdagangkan. Adapun istilah komersialisasi pendidikan saat ini mengacu pada dua pengertian yang berbeda yakni:

Pertama, komersialisasi pendidikan yang mengacu lembaga pendidikan dengan program serta perlengkapan mahal. Pada pengertian ini, pendidikan hanya dapat dinikmati oleh sekelompok masyarakat ekonomi kuat, sehingga lembaga seperti ini tidak dapat disebut dengan istilah komersialisasi karena mereka memang tidak memperdagangkan pendidikan. Pemungutan biaya yang tinggi adalah untuk menfasilitasi jasa pendidikan serta menyediakan infrastruktur pendidikan yang bermutu, seperti menyediakan fasilitas teknologi informasi, laboratorium dan perpustakaan yang baik, serta memberikan kepada para guru atau dosen gaji menurut standar. Sisa anggaran yang mereka peroleh, mereka tanamkan kembali bentuk infrastruktur pendidikan. Komersialisasi pendidikan jenis ini tidak akan mengancam idealisme pendidikan nasional atau idealisme Pancasila, akan tetapi perlu dicermati juga, karena dapat menimbulkan pendiskriminasian dalam pendidikan nasional. ${ }^{2}$

Kedua, komersialisasi pendidikan yang mengacu kepada lembaga pendidikan yang hanya mementingkan uang pendaftaran dan uang kuliah saja, tetapi mengabaikan kewajibankewajiban pendidikan. ${ }^{3}$ Komersialisasi pendidikan ini biasanya, dilakukan oleh lembaga atau sekolah-sekolah yang menjanjikan pelayanan pendidikan tetapi tidak sepadan dengan uang yang mereka pungut. Pada lembaga atau sekolah yang seperti ini, laba atau selisih anggaran yang diperoleh tidak ditanam kembali ke dalam infrastruktur pendidikan, melainkan dipergunakan untuk memperkaya atau menghidupi pihak-pihak yang tidak secara langsung bekerja menyajikan pelayanan di lembaga tersebut. Pihak-pihak tersebut adalah anggota yayasan atau badan amal pendidikan yang menguasai lembaga pendidikan. Itu hal yang lebih berbahaya lagi, komersialisasi jenis kedua ini dapat pula melaksanakan praktik pendidikan untuk maksud memburu gelar akademik tanpa melalui proses serta mutu yang telah ditentukan sehingga dapat membunuh idealisme pendidikan Pancasila. Hal tersebut jelas tercantum di dalam Undang-Undang No. 20 Tahun 2003 tentang Sistem Pendidikan Nasional pada bab 1 pasal 1 yang berbunyi: "Pendidikan adalah usaha sadar dan terencana untuk mewujudkan suasana belajar dan proses pembelajaran agar peserta didik secara aktif mengembangkan potensi dirinya untuk memiliki kekuatan spiritual keagamaan, pengendalian diri, kepribadian, kecerdasan, akhlak yang mulia serta keterampilan yang diperlukan dirinya, masyarakat bangsa dan negara". ${ }^{4}$ Dalam UU tersebut jelas dinyatakan bahwa pendidikan itu

\footnotetext{
${ }^{2}$ Irawaty A. Kahar. Komersialisasi Pendidikan di Indonesia: Suatu Tinjauan dari Aspek Politik, Ekonomi, Sosial, dan Budaya. dalam Majalah Universitas Sumatera Utara Edisi No. 23/Tahun XI/Januari 2007 Rubrik Ragam-Historisme.

${ }^{3}$ Muchtar Buchori. Komersialisasi Idealisme Bukan Tabu. Yogyakarta: Kanisius, 2001.

${ }^{4}$ Undang-Undang No. 20 Tahun 2003 tentang Sistem Pendidikan Nasional
} 
harus melalui proses belajar dan berakhlak mulia, mungkin ini kurang terdapat dalam komersialisasi pendidikan jenis kedua di atas.

Kedua pengertian diatas apabila dipahami kata-per-kata tentunya akan dilihat perbedaannya. Secara singkat kecenderungan pengertian pertama lebih kepada penjelasan atas mahalnya biaya dengan fasilitas pendidikan yang mewah, lengkap, tenaga pengajar berkualitas dan bertaraf Internasional, sedangkan pengertian kedua bermakna komersialisasi didasarkan pada pengambilan keuntungan semata untuk mencapai hasil dan gelar dengan jalan pintas tanpa melalui proses pembelajaran. Dari kedua jenis komersialisasi itu, maka komersialisasi jenis kedua dianggap tidak berkualitas yang akan berpengaruh pada sumber daya manusia yang dihasilkan kelak.

\section{B. Komersialiasi dan Tata Kelola Pendidikan Tinggi}

Walaupun komersialisasi pendidikan pada dasarnya mendatangkan keuntungan keuangan bagi penyelenggara pendidikan tinggi. Namun dampak komersialisasi tersebut lambat laun akan terasa dalam proses tata kelola pendidikan tinggi. Hal ini secara gamblang disampaikan oleh Derek Bok yang secara khusus menyebut beberapa kerugian yang harus dibayar atas pilihan menjalankan komersialisasi pendidikan. Kerugian tersebut antara lain: komersialisasi dapat merongrong standar akademik, komersialisasi dapat meronrong semangat kolegialitas dan kepercayaan di antara anggota komunitas akademik, dan komersialisasi dapat merusak citra universitas di mata publik.

Pertama, komersialisasi dapat merongrong standar akademik. Contoh nyata dalam masalah ini terdapat pada pola perekrutan dosen. Calon yang lebih diutamakan adalah calon yang mempunyai koneksi dengan dunia bisnis dan kemungkinan besar dapat mendatangkan proyek kerjasama yang secara finansial menguntungkan tanpa memperhatikan kualifikasinya sebagai tenaga pengajar dan pendidik, standar akademik universitas itu cepat atau lambat akan merosot. Demikian juga kalau dalam merekrut dosen pertimbangan utamanya adalah mana yang jenis penelitiannya akan mendatangkan hak paten yang menunjang kepentingan bisnis, tetapi tidak memperhatikan kemampuannya dalam mengajar dan membimbing mahasiswa melakukan penelitian yang baik, rekrutmen seperti itu juga akan memerosotkan standar akademik. Hal ini telah banyak terlihat di pendidikan tinggi di Indonesia. Maraknya perekrutan dengan atas pertimbangan menambah kapitral dapat mengakibatkan tenaga pendidikan tersebut diragukan dan tidak berkualifikasi terhadap bidang yang digelutinya.

Komersialisasi dapat mengancam prinsip kependidikan karena motif mencari untung dapat menggeser fokus dari menyediakan sarana pembelajaran yang terbaik yang secara optimal dapat diberikan berdasarkan sumber daya yang ada, ke upaya menaikkan pendapatan sebesar-besarnya dengan mengurangi biaya sampai sekecil mungkin tanpa kehilangan pelanggan. Universitas yang sudah ternama memungut biaya pendidikan yang amat mahal, tetapi tidak mengimbangi dengan mutu layanan yang memadai. Para dosen seniornya jarang mengajar, sehingga para mahasiswa lebih sering diajar oleh asisten dosen. 
Motif mengejar untung dapat mengakibatkan universitas dapat mengurangi luas layanan yang seharusnya guna memperoleh surplus yang lebih besar. Misalnya program studi MBA hanya buka untuk kelas eksekutif dengan bayaran mahal, sehingga hanya para manajer dari perusahaan yang besar saja yang dapat masuk sedangkan para manajer dari perusahaan yang kecil yang sebenarnya potensial tidak mendapatkan akses. Penelitian ilmiah yang disponsori suatu perusahaan, hasilnya tidak jarang tidak boleh dipublikasikan secara umum karena akan menguntungkan perusahaan pesaing dan merugikan perusahaan pemasok dana. Tetapi kerahasiaan hasil penelitian ilmiah ini mengurangi luas layanan yang seharusnya diberikan oleh universitas.

Komersialisasi pendidikan juga dapat menimbulkan kerugian moral berupa sikap sinis para mahasiswa terhadap prinsip-prinsip moral yang ingin diperjuangkan oleh lembaga karena mereka melihat dengan mata kepala sendiri bagaimana prinsip-prinsip yang digariskan dalam kode etik perguruan tinggi dan diajarkan di kelas itu terang-terangan dikhianati oleh lembaga tempat mereka belajar. Misalnya kalau di kampus terjadi jual beli nilai atau soal ujian hanya karena para dosennya cenderung mata duitan, nilai kejujuran akademik dan disiplin kerja keras di kampus itu akan merosot. Kesetiaan dan kepatuhan pada aturan main akademik dalam melakukan penelitian ilmiah juga akan tidak terjadi. Kalau pimpinan Perguruan Tinggi mau menerima sejumlah uang dari suatu perusahaan sebagai pelicin ijin untuk menggunakan kampus untuk tempat jualan produknya, kiranya secara moral akan mengalami kesulitan untuk melarang mahasiswanya yang menerima beasiswa dari sebuah perusahaan dengan syarat dia menjadi "sales promotion girl" untuk produk perusahaan tersebut di kampusnya. ${ }^{5}$

Kedua, komersialisasi dapat meronrong semangat kolegialitas dan kepercayaan di antara civitas akademika dengan menciptakan pemisahan dan ketegangan yang sebelumnya tidak ada di antara civitas akademika. ${ }^{6}$ Misalnya, dosen yang sebelumnya kerja keras dengan melaksanakan tugas-tugas akademiknya secara setia, akan menjadi tidak suka terhadap koleganya yang sebenarnya juga dosen tetap tetapi dalam praktek menjadi dosen luar biasa (atau lebih tepat disebut biasa di luar) karena sibuk berbisnis atau memberi konsultasi sana sini. Para dosen ilmu-imu kemanusiaan dan budaya akan merasa kurang dihargai oleh pimpinan yang sering mengagung-agungkan dosen-dosen bidang studi yang lebih mendatangkan uang ke lembaga. Friksi juga akan terjadi kalau pimpinan memandang para profesor peneliti yang mendatangkan hak paten lebih berharga bagi lembaga sehingga digaji jauh lebih tinggi dibandingkan para dosen biasa yang setia mengajar dan membimbing para mahasiswa. Para mahasiswa program pasca sarjana akan merasa dimanfaatkan oleh dosennya kalau hasil penelitian mereka digunakan begitu saja di perusahaan tempat dosen tersebut menjadi konsultannya, sehingga dalam melakukan penelitian mereka juga akan kehilangan rasa percaya dan sikap hormat kepada dosen tersebut.

\footnotetext{
${ }^{5}$ Derek Bok. Universities in the Marketplace. Commercialization of Higher Education. Princeton: Princeton University Press, 2003. hh. 108-113.

${ }^{6}$ Ibid. hh. 113-115.
} 
Ketiga, komersialisasi dapat merusak citra universitas di mata publik. ${ }^{7}$ Secara tradisional universitas termasuk lembaga yang layak dipercaya oleh publik karena universitas ada untuk suatu tujuan luhur demi kepentingan umat manusia secara keseluruhan. Pada umumnya publik percaya bahwa di situ pihak-pihak yang terlibat di dalamnya berkomitmen mengejar tujuan bersama yang tidak hanya mencari keuntungan diri sendiri. Sebaliknya, mereka berdedikasi untuk mencari dan menemukan kebenaran serta mengembangkan dalam diri para mahasiswanya kemampuan berpikir, bercitarasa keindahan dan bertindak secara bertanggung jawab.

Para dosen yang mengajar di universitas umumnya bersedia memperoleh gaji yang relatif lebih rendah dibandingkan dengan orang-orang yang memiliki intelegensi dan pendidikan kurang lebih sebanding dengan mereka tetapi bekerja di dunia bisnis, karena mereka memiliki idealisme hidup yang tidak sepenuhnya dapat dinilai dengan uang. Komersialisasi pendidikan dapat menggerogoti nama baik universitas apabila universitas tidak lagi mengindahkan standar akademik dan melulu mencari untung finansial dengan memperdagangkan apa saja yang dapat diproduksikannya. Lebih penting lagi, komersialisasi pendidikan dapat mengancam citra universitas sebagai lembaga tempat pengajaran dan penelitian yang objektif dan tidak mencari keuntungan diri sendiri. Ketika fakultas kedokteran, misalnya, membiarkan perusahaan farmasi memanipulasi hasil uji klinis di laboratorium, karena telah memasok dana ke fakultas tersebut, manakala para dosen mempublikasikan tulisan-tulisan hasil penelitian yang masih kontroversial tetapi menunjang kepentingan suatu perusahaan di mana ia juga berkepentingan secara pribadi, ketika para dekan fakultas membiarkan perusahaan memasukkan iklan produk mereka sebagai bagian dari materi perkuliahan di fakultasnya, publik akan mulai mempertanyakan kebebasan dan sikap tak memihak dari universitas tersebut. Dengan demikian integritas universitas akan terancam.

Demikianlah kalau dilihat secara keseluruhan, biaya yang harus dibayar dalam bentuk yang tidak selalu kasat mata atau tidak selalu dapat dihitung dengan uang semata, ternyata lebih besar daripada keuntungan atau manfaat yang dapat diperoleh daripadanya. Maka mengambil hal-hal yang positif dari dunia bisnis demi peningkatan efisiensi kerja, kualitas hasil didikan dan kinerja semua pihak yang terlibat serta demi pengembangan Perguruan Tinggi ke depan, merupakan hal yang layak didukung di era pasar global ini. Tetapi membiarkan kekuatan pasar menggerogoti integritas universitas sebagai lembaga akademik hanya akan merusak citra lembaga pendidikan tersebut di mata publik.

\section{Strategi Pendidikan Tinggi dalam Menghadapi Dampak Komersialisasi}

Apabila kita berbicara mengenai strategi pendidikan tinggi dalam menghadapi dampak komersialisasi maka hal ini perlu dipisahkan antara pendidikan tinggi negeri maupun pendidikan tinggi swasta. Karena pada dasarnya pendidikan tinggi negeri masih ada tanggungan dari pemerintah, namun swasta tidak ditanggung oleh pemerintah melainkan

\footnotetext{
${ }^{7}$ Ibid. $115-118$
} 
secara mandiri mengelola keuangannya. Berikut strategi yang dapat dilakukan oleh pendidikan tinggi dalam menghadapi dampak komersialisasi:

\section{1) Bagi Pendidikan Tinggi Negeri}

Munculnya komersialisasi pendidikan di pendidikan tinggi negeri yang notabene merupakan milik pemerintah merupakan akibat dari pelepasan tanggung jawab pemerintah yang telah mencabut subsidi pembiayaan terutama pada perguruan tinggi dan pemberian hak otonomi serta status BHMN pada perguruan tinggi negeri. Hal ini mengakibatkan ideologi kapitalisme mulai merebak di dalam dunia pendidikan yang pada akhirnya lebih mengutamakan keuntungan bagi pihak-pihak tertentu saja. Adapun upaya yang dapat dilakukan pendidikan tinggi negeri untuk menyiasati terjadinya komersialisasi pendidikan ini yakni:

a) Mempertahankan mutu pendidikan dan menjaga agar pola akses masuk anak didik untuk masuk perguruan tinggi negeri tetap pada jalur semestinya, seperti SNMPTN.

b) Mengusahakan bentuk-bentuk pengumpulan modal untuk membiayai pendidikan dengan cara menanamkan modal di bursa atau sertifikat Bank Indonesia, obligasi/swasta yang dapat memberikan keuntungan hingga dapat dipergunakan Universitas. Dengan cara seperti ini modal pokok tidak terpakai (seperti: Jamsostek). Untuk operasionalnya: harus ada Fund Manager yang duduk di Universitas yang ahli dalam pemutaran dan mencari saluran dana yang dapat memberikan keuntungan untuk membiayai universitas.

\section{2) Bagi Pendidikan Tinggi Swasta}

Untuk pendidikan tinggi swasta, komersialisasi memang tidak dapat terhindarkan lagi. Komersialisasi di pendidikan tinggi swasta merupakan tempat yang paling rawan untuk dilakukan praktik-praktik yang dapat merusak citra dari pendidikan tinggi swasta secara keseluruhan. Maka dari itu, strategi yang perlu dilakukan yakni:

a) Melakukan koordinasi penuh dengan Kopertis (Koordinator Perguruan Tinggi Swasta) yang terdapat di wilayah masing-masing agar terciptanya komunikasi yang baik, sehingga Kopertis dapat menaungi dan mengontrol institusi pendidikan tinggi tersebut.

b) Meningkatkan mutu pendidikan melalui pengembangan kemampuan siswa agar dapat bersaing dengan lulusan dari pendidikan tinggi lainnya.

c) Melakukan efisiensi terhadap pengeluaran yang tidak prioritas untuk menekan terjadinya lonjakan kenaikan biaya pendidikan. 


\section{BAB III. PENUTUP}

\section{A. Kesimpulan}

Dari pembahasan diatas dapat disimpulkan bahwa pengertian komersialisasi pendidikan dapat dikategorikan ke dalam dua hal yakni, 1) komersialisasi pendidikan yang mengacu lembaga pendidikan dengan program serta perlengkapan mahal, maupun 2) komersialisasi pendidikan yang mengacu kepada lembaga pendidikan yang hanya mementingkan uang pendaftaran dan uang kuliah saja, tetapi mengabaikan kewajibankewajiban pendidikan.

Dampak yang ditimbulkan oleh komersialisasi pendidikan terhadap tata kelola pendidikan tinggi antara lain: 1) komersialisasi dapat merongrong standar akademik, 2) komersialisasi dapat meronrong semangat kolegialitas dan kepercayaan di antara anggota civitas akademika dengan menciptakan pemisahan dan ketegangan yang sebelumnya tidak ada, dan 3) komersialisasi dapat merusak citra universitas di mata publik.

Seiring merebaknya komersialisasi ini, maka sepatutnya pendidikan tinggi mempunyai strategi yang dapat dilakukan untuk menyiasati agar komersialisasi pendidikan ini tidak sampai mengorbankan peserta didik. Dalam hal ini, dibedakan dua strategi yang diberikan yakni pada pendidikan tinggi negeri, dan pendidikan tinggi swasta. Untuk pendidikan tinggi negeri strategi yang dapat dilakukan antara lain: a) mempertahankan mutu pendidikan dan menjaga agar pola akses masuk anak didik untuk masuk perguruan tinggi negeri tetap pada jalur semestinya, seperti SNMPTN, b) mengusahakan bentuk-bentuk pengumpulan modal untuk membiayai pendidikan dengan cara menanamkan modal di bursa atau sertifikat Bank Indonesia, obligasi/swasta yang dapat memberikan keuntungan hingga dapat dipergunakan Universitas.

Sedangkan untuk pendidikan tinggi swasta, strategi yang dapat dilakukan yakni: a) melakukan koordinasi penuh dengan Kopertis (Koordinator Perguruan Tinggi Swasta) yang terdapat di wilayah masing-masing agar terciptanya komunikasi yang baik, sehingga Kopertis dapat menaungi dan mengontrol institusi pendidikan tinggi tersebut, b) meningkatkan mutu pendidikan melalui pengembangan kemampuan siswa agar dapat bersaing dengan lulusan dari pendidikan tinggi lainnya, dan c) melakukan efisiensi terhadap pengeluaran yang tidak prioritas untuk menekan terjadinya lonjakan kenaikan biaya pendidikan. 


\section{BIBLIOGRAPHY}

A. Kahar, Irawaty. Komersialisasi Pendidikan di Indonesia: Suatu Tinjauan dari Aspek Politik, Ekonomi, Sosial, dan Budaya. dalam Majalah Universitas Sumatera Utara Edisi No. 23/Tahun XI/Januari 2007 Rubrik Ragam-Historisme.

Barrow, Robin. An Introduction to Philosophy of Education. London: Routledge Woods, 2000 .

Buchori, Muchtar. Komersialisasi Idealisme Bukan Tabu. Yogyakarta: Kanisius, 2001.

Bok, Derek. Universities in the Marketplace. Commercialization of Higher Education. Princeton: Princeton University Press, 2003.

Indrajit, R. Eko, dan R. Djokopranoto. Manajemen Perguruan Tinggi Modern. Yogyakarta: Penerbit Andi, 2006.

Ronald, Blake, et. al.. The Blackwell Guide to the Philosophy of Education, MA: Blackwell Publishing Ltd, 2003.

S.J., J. Sudarminta. Postmodernisme dan Komersialisasi Pendidikan Tinggi. dalam Globalisasi dan Pemanfaatan Teknologi Industri: Tantangan dan Peluang bagi Perguruan Tinggi, Yogyakarta: APTIK, 2010.

Winarno, Budi. Isu-Isu Global Kontemporer. Yogyakarta: Center for Academic Publishing Service, 2011. 